The earthquakes have their foci at depths ranging from the surface to some $100 \mathrm{~km}$, though normally the depth is about $13 \mathrm{~km}$. The deeper foci lie roughly on an east-west line starting from near the centre of the west coast of Turkey-in-Asia. The shocks vary greatly in magnitude; there are about eight shocks a year of magnitude 5 or greater on the Richter logarithmic scale. The earthquakes often begin from old foci, occasionally from new ones, and many of these are not near towns. An earthquake at Erzincan on December 26-27, 1939, killed 23,148 people and injured 8,029. 16,629 buildings were completely destroyed (see Nature, 145, 13; 1940).

Most Turkish earthquakes are of tectonic origin, due to "Alpine" orogenic pressure. Slipping occurs when this pressure exceeds that required for movement, usually along one or more of the deep ancient geological faults which abound. The first point which yields becomes an earthquake focus. One such structural line runs through Mürefte, Izmit, Bolu and Gerede, and, although it is a line of earthquake epicentres, it also has such an influence on relief that it is both a very densely populated zone and a corridor for communications. Two other active faults are the Kayas and Akpinar faults.

The general geological structure of Turkey awaits clarification. Three ideas at present hold the arena: (a) that it merely consists of strong transverse anticlines and synclines, sometimes faulted along the edges; (b) that it consists of a "Zwischengebirge" between the Pontine and Taurus Mountains; (c) that at Kirsehir is a Pontine nappe and that the Anatolian thrust at its base is essentially a boundary between the Pontic (Black Sea) and Taurus (Mediterranean) pre-Tertiary rocks which differ in facies.

On account of the enhanced interest at the University of Istanbul, Turkey is now better provided with seismograph stations than formally, and some advanced seismological work is being undertaken. N. Canitez and S. B. Ucer have recently recomputed all Turkish epicentres between January 1947 and December 1959, using a digital computer. The accuracies of the new epicentres and times of origin are about $\pm 0 \cdot 1$ degrees and $1 \cdot 0$ seconds respectively. $P_{n}$ arrivals at epicentral distances less than $16^{\circ}$ were used, together with an iteration method which used the local velocity of $P_{n}$ waves. The standard deviation in both latitude and longitude for the new epicentres is less than $\pm 0 \cdot 1$ degree. The same authors have also investigated the mechanism of some seventy earthquakes which occurred in or near Turkey between the years 1936 and 1965 .

\section{Help with Computers}

The Ministry of Technology is continuing to support the development in Britain of new computer techniques. It has just announced that, under its Advanced Computer Techniques Project, twenty-one new contracts worth more than $£ 1$ million, and supported jointly by the Government and industry, have been placed in the past year. The Government has also allocated an additional $£ 600,000$ for new contracts which are expected to be placed by April 1967.

The project was started under the Department of Scientific and Industrial Research in 1963, when the then government considered there was not enough research and development to maintain a viable com- petitive position in the world computer market. Seven contracts costing about $£ 325,000$ have been completed so far. The ministry's aim is to support projects which are too uncertain or too long term to commend themselves to industry, but which lie in areas that must be developed if the industry is to grow.

The prevailing view is that research and development are chiefly required in the development of fast storage devices, the design of systems and in the working out of a cheap and reliable technology of peripheral equipment and software.

\section{Fresh Fish to Eat}

THE report for 1965 of the Director of the Torry Research Station (H.M.S.O., 5s. 6d.) lays greatest stress on the need for technical innovation in the British fishing industry. The traditional fishing grounds are yielding fewer fish of the types most appreciated by the British public-cod, haddock, plaice and herring - so that the station's development of methods which minimize wastage of fish between catching and consumption is of particular importance. Superchilling of fish in liquid air, pre-packaging wet fish and dip coating of fish in liquids which produce a flexible surface film are methods which have been tried. Another possibility is to fillet the fish before freezing at sea in order to eliminate thawing and refreezing of fish for filleting to be carried out.

Even if spoilage of fish is minimized, however, it seems unlikely that all needs can be satisfied without the introduction of hitherto unexploited species such as redfish, dogfish, saithe and mackerel. These fish could be marketed in traditional ways or as components of made-up products such as fish sausages or fish cakes. A further possibility is to extend the fishing grounds to the South Atlantic, and work has been done on the preservation of fish at higher ambient temperatures in preparation for such a development.

Since these problems are essentially of a practical nature, a shift in the emphasis of the station's work away from basic research has occurred, and will be encouraged. Basic research work, however, still makes up a considerable proportion of the station's effort, and bacteriological and biochemical investigations have continued to be carried out.

\section{Microbiologists in Moscow}

AT the end of July over five thousand microbiologists from nearly fifty countries assembled at Moscow State University for their ninth quatrennial congress. More than 1,500 papers were presented or made open for discussion and they covered most aspects of microbiology. Statistics such as these immediately raise the obvious question of the usefulness of this kind of meeting (writes one of the participants). Indeed, the poor standard of many of the communications was such that one would have wished for a more thorough selection in the preparation of the programme. Be that as it may, a great deal of interest emerged during the course of the congress which afforded-and which, through the agency of its published proceedings, will continue to afford-an ideal opportunity for microbiologists to survey their rapidly expanding subject.

One of the undoubted consequences of this huge meeting was the chance of informal discussion with colleagues, and a recurrent theme in these exchanges, 